\title{
Review of Survey activities 2009
}

\section{Edited by}

Ole Bennike, Adam A. Garde and W. Stuart Watt 


\section{Geological Survey of Denmark and Greenland Bulletin 20}

\section{Keywords}

Geological Survey of Denmark and Greenland, survey organisations, current research, Denmark, Greenland.

\section{Cover photographs from left to right}

1. The Swedish ice breaker Oden at the North Pole during the LOMROG II cruise on 22 August 2009. Photo: Adam Jeppesen.

2. Folded Permian volcanic rocks in Vietnam. Photo: Stig A. Schack Pedersen.

3. Field work in West Greenland. Photo: Denis Schlatter.

4. A seismometer is placed in a pit on the Greenland ice sheet. Photo: Hans Thybo.

\section{Frontispiece: facing page}

Tanzanian woman using mercury to extract gold. Photo: Peter W.U. Appel.

Chief editor of this series: Adam A. Garde

Editorial board of this series: John A. Korstgård, Department of Earth Sciences, University of Aarhus; Minik Rosing, Geological Museum, University of Copenhagen; Finn Surlyk, Department of Geography and Geology, University of Copenhagen

Scientific editors: Ole Bennike, Adam A. Garde and W. Stuart Watt

Editorial secretaries: Jane Holst and Esben W. Glendal

Referees: (DK = Denmark etc.; numbers refer to first page of reviewed article): Anonymous (43, 83, 99); James D. Appleton, UK (87); Stefan Bachu, CA (95); Terje Bjerkgård, NO (59); Didier Bonijoly, FR (95); Gregers Dam, DK (75); David Lundbek Egholm, DK (55); Ida Fabricius, DK (15, 47); Henrik Friis, DK (47); Ole Graversen, DK (99); Robert Hall, GB (91); Claus Heinberg, DK (75); Karin Högdahl, SE (71); Cecilia Jelinek, SE (39); Birthe Eg Jordt, DK (27); Ralf Klingel, DE (39); Karen Luise Knudsen, DK (35); John A. Korstgård, DK (51); Gunnar Larsen, DK (31); Nicolaj Krog Larsen, SE (31); Kaj Lax, SE (103); Jan Mangerud, NO (35); Christoph Mayer, DE (55); Sebastian Mernild, US (79); John Myers, AU (67); Allan Aasbjerg Nielsen, DK (71); Ole Bjørslev Nielsen, DK (23); Poul Østergaard, DK (19); Heikki Papunen, FR (63); Christophe Pascal, NO (19); Asger Ken Pedersen, DK (59); Gunver Krarup Pedersen, DK (23); Iain Pitcairn, SE (63); Martin Sønderholm, DK (51); Jette Sørensen, DK (27); Henrik Stendal, GL (87); Holger Stünitz, NO (67); Ole V. Vejbæk, DK (15); Ian Watkinson, GB (91); Jacob Clement Yde, NO $(79,83)$

Illustrations: Stefan Sølberg, with contributions from Jette Halskov, Eva Melskens and Benny M. Schark

Layout and graphic production: Annabeth Andersen

Printers: Rosendahls · Schultz Grafisk A/S, Albertslund, Denmark

Manuscripts submitted: 13 January - 16 April 2010

Final versions approved: February-May 2010

Printed: 7 July 2010

ISSN 1603-9769 (Review of Survey activities)

ISSN 1604-8156 (Geological Survey of Denmark and Greenland Bulletin)

ISBN 978-87-7871-282-0

\section{Citation of the name of this series}

It is recommended that the name of this series is cited in full, viz. Geological Survey of Denmark and Greenland Bulletin. If abbreviation of this volume is necessary, the following form is suggested: Geol. Surv. Den. Green. Bull. 20, 106 pp.

\section{Available from}

Geological Survey of Denmark and Greenland (GEUS)

Øster Voldgade 10, DK-1350 Copenhagen K, Denmark

Phone: +4538 142000, fax: +45381420 50, e-mail: geus@geus.dk

And at www.geus.dk/publications/bull

(C) De Nationale Geologiske Undersøgelser for Danmark og Grønland (GEUS), 2010

For the full text of the GEUS copyright clause, please refer to www.geus.dk/publications/bull 
$65-2, y$ 3 (1)
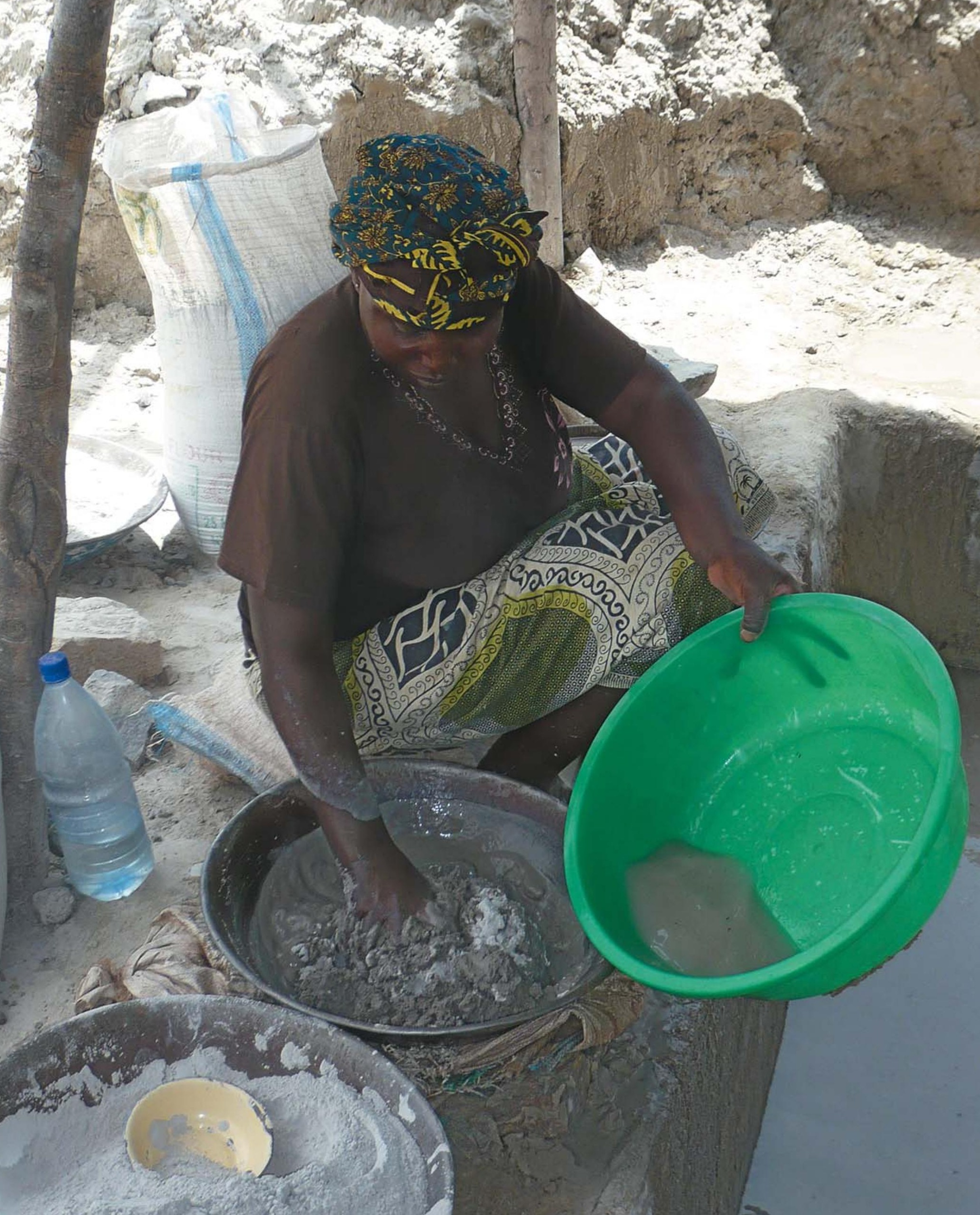

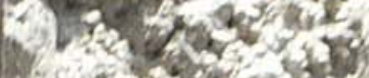

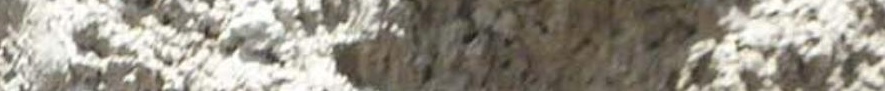

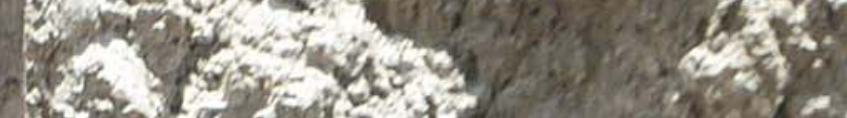
$\rightarrow=20$ and + 5 -

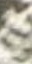

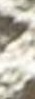




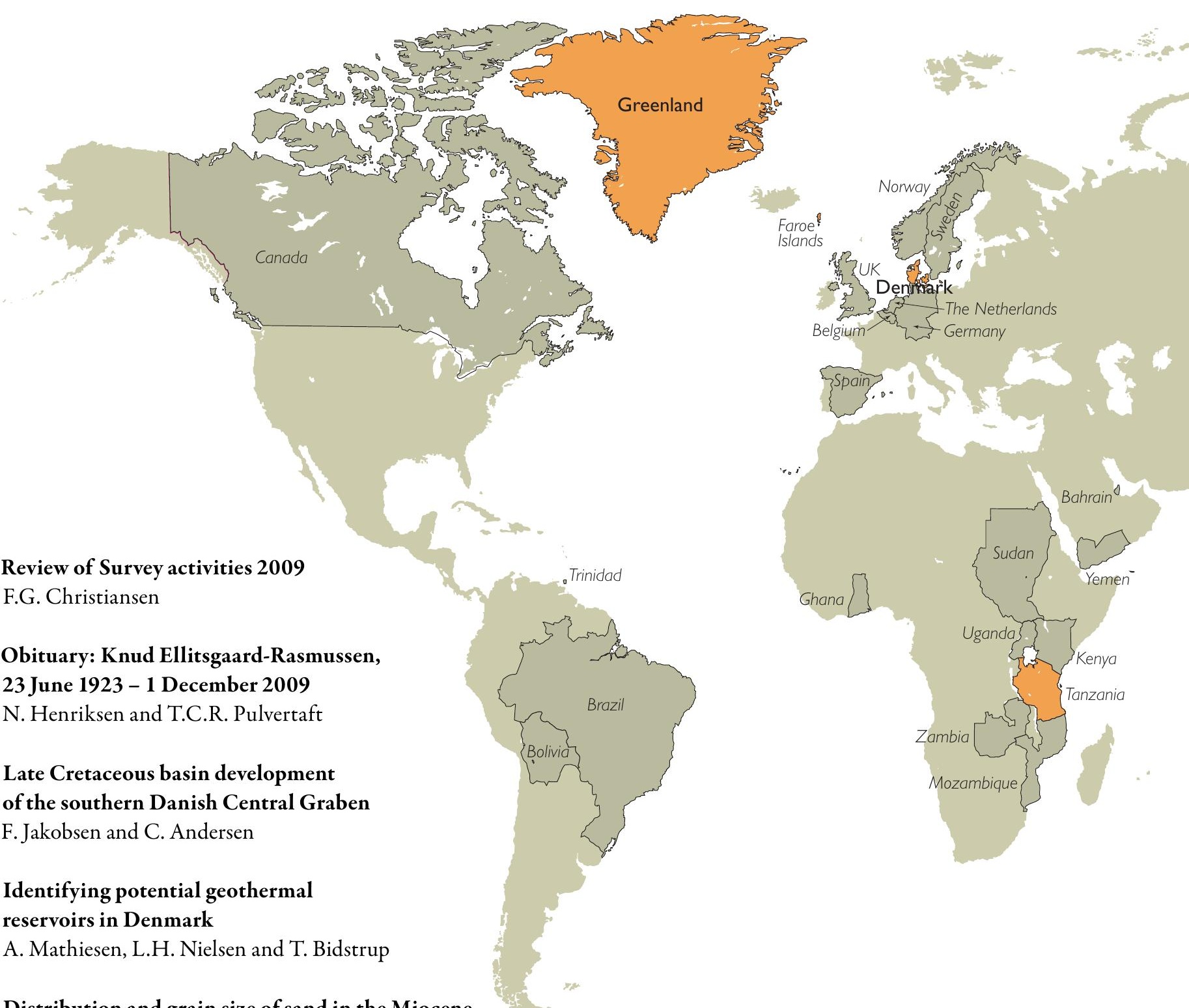

23 Distribution and grain size of sand in the Miocene wave-dominated Billund delta, Denmark E.S. Rasmussen and J. Bruun-Petersen

43 Recent changes in the nutrient status of a soft-water Lobelia lake, Hampen Sø, Denmark

K. Weckström, P. Rasmussen, B.V. Odgaard, T.J. Andersen, T. Virtanen and J. Olsen

27 3-D geological modelling of the Egebjerg area, Denmark, based on hydrogeophysical data

F. Jørgensen, R.R. Møller, P.B.E. Sandersen and L. Nebel

47 Silica diagenesis and its effect on porosity of upper Maastrichtian chalk - an example from the Eldfisk Field, the North Sea

H.B. Madsen area in the Kattegat, southern Scandinavia J.O. Leth and B. Novak

35 Amino acid analysis of pre-Holocene foraminifera from Kriegers Flak in the Baltic Sea

O. Bennike and B. Wagner

39 Radon content in Danish till deposits: relationship with redox conditions and age P. Gravesen and P.R. Jakobsen

51 The Continental Shelf Project of the Kingdom of Denmark - status at the beginning of 2010

C. Marcussen and M.V. Heinesen

55 Greenland ice sheet monitoring network (GLISN): a seismological approach T. Dahl-Jensen, T.B. Larsen, P.H. Voss and the GLISN group 


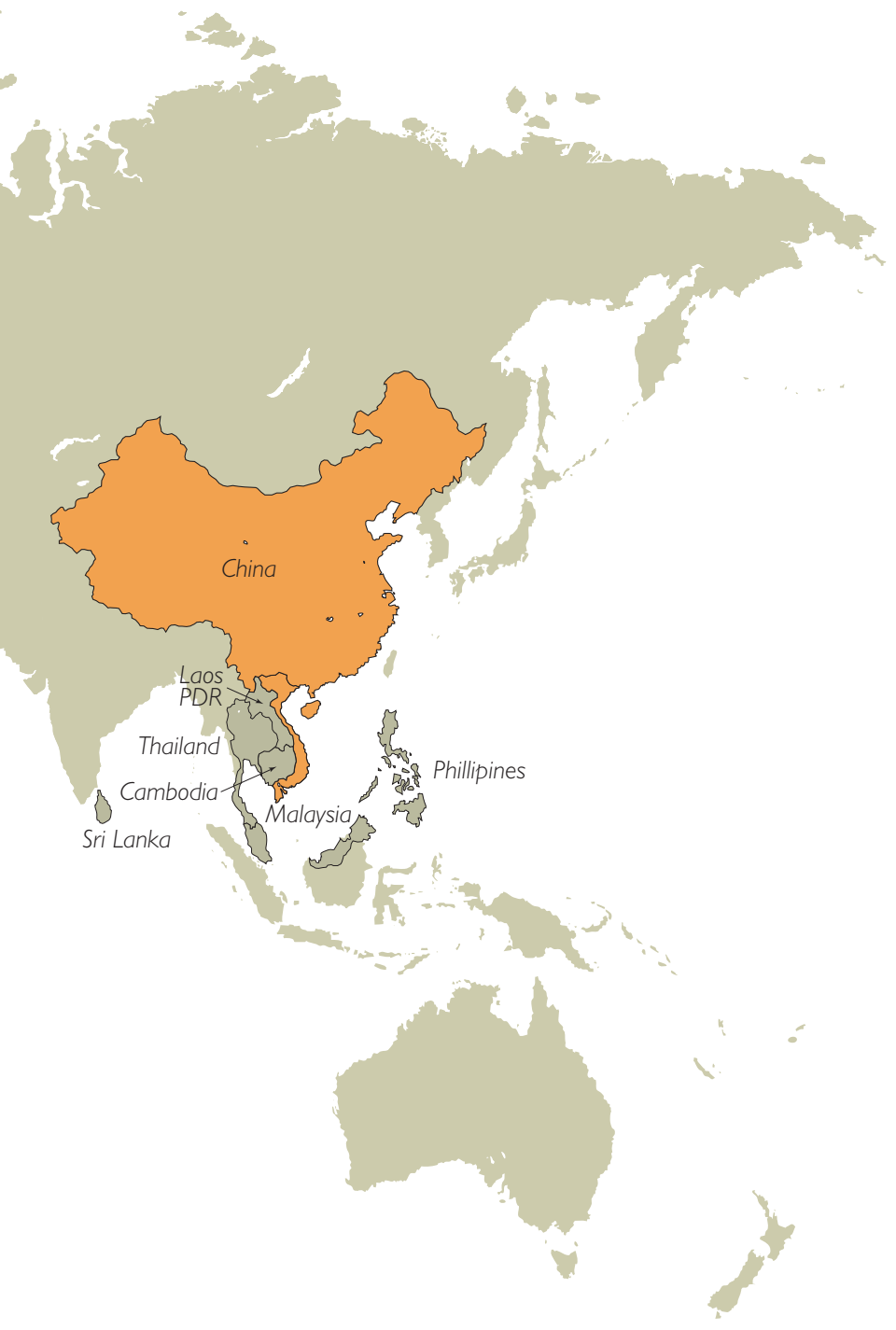

59 The mineral resource assessment project, South-East Greenland: year one B.M. Stensgaard, J. Kolb, T.F.D. Nielsen, S.D. Olsen, L. Pilbeam, D. Lieber and A. Clausen

63 Characterisation of host rocks and hydrothermal alteration of the Qussuk gold occurrence, southern West Greenland

D.M. Schlatter and R. Christensen

67 Zircon record of the igneous and metamorphic history of the Fiskenæsset anorthosite complex in southern West Greenland N. Keulen, T. Næraa, T.F. Kokfelt, J.C. Schumacher and A. Scherstén

71 Application of airborne hyperspectral data to mineral exploration in North-East Greenland T. Tukiainen and B. Thomassen
GEUS working areas 2009.

Orange areas are covered in this volume.

For further information on other working areas please refer to $w w w . g e u s . d k /$ international

75 Study of a Palaeogene intrabasaltic sedimentary unit in southern East Greenland:

from 3-D photogeology to micropetrography H. Vosgerau, P. Guarnieri, R. Weibel, M. Larsen, C. Dennehy, E.V. Sørensen and C. Knudsen

79 An advancing glacier in a recessive ice regime: Berlingske Brx, North-West Greenland P.R. Dawes and D. van As

83 Bathymetry, shallow seismic profiling and sediment coring in Sermilik near Helheimgletscher, South-East Greenland C.S. Andresen, N. Nørgaard-Pedersen, J.B. Jensen and B. Larsen

87 Borax - an alternative to mercury for gold extraction by small-scale miners: introducing the method in Tanzania P.W.U. Appel and J.B. Jønsson

91 Vietnamese sedimentary basins: geological evolution and petroleum potential M.B.W. Fyhn, H.I. Petersen, A. Mathiesen, L.H. Nielsen, S.A.S. Pedersen, S. Lindström, J.A. Bojesen-Koefoed, I. Abatzis and L.O. Boldreel

95 Potential for permanent geological storage of $\mathrm{CO}_{2}$ in China: the $\mathrm{COACH}$ project N.E. Poulsen

99 Thin-skinned thrust-fault tectonics offshore south-west Vietnam S.A.S. Pedersen, L.O. Boldreel, E.B. Madsen, M.B. Filtenborg and L.H. Nielsen

103 Interactive web analysis and presentation of computer-controlled scanning electron microscopy data

P. Riisager, N. Keulen, U. Larsen, R.K. McLimans, C. Knudsen and J. Tulstrup 



\title{
Review of Survey activities 2009
}

\author{
Flemming G. Christiansen
}

Deputy Director

2009 was a favourable year for the Geological Survey of Denmark and Greenland (GEUS) with focus on research, often in international collaboration. Many new projects have been initiated and many completed. In 2009, Copenhagen hosted COP15, and GEUS' involvement in the preparation for this event focussed on climate changes, reducing consumption of fossil fuels and $\mathrm{CO}_{2}$ emissions.

This is also reflected in this seventh issue of Review of Survey activities that describes many projects that GEUS and its partners carry out in Denmark, Greenland and abroad. Together with the previous six issues, it provides a good overview of the Survey's range of research and advisory activities. The review contains a total of 23 four-page papers: nine on Scandinavia, primarily Denmark, one on the continental shelf project, eight on Greenland, four on international work and one on data management.

In addition, an obituary about Knud Ellitsgaard-Rasmussen, 1923-2009, is given. He was the first leader and subsequently formal director of the Geological Survey of Greenland (GGU) until he retired in 1983. The obituary gives an interesting overview of the post-war initiation and early history of GGU - merged in 1995 with the Geological Survey of Denmark (DGU) to form the present Geological Survey of Denmark and Greenland.

Energy policy is again high on the political agenda in Denmark. The financial crisis has emphasised the importance of revenues from the North Sea oil production, at a time when we also see strong national and international political demands for reduction of $\mathrm{CO}_{2}$ emissions. GEUS gives high priority to research within both topics - but also to research on climate development, climate monitoring and adaptation to climate changes.

Two papers concentrate on petroleum geology in Denmark. One provides an overview of the Late Cretaceous basin development of the southern Danish Central Graben where most of the Danish oil and gas producing fields are found; the other discusses silica diagenesis and its effect on the porosity of impure Maastrichtian chalk.
Denmark has a large potential for subsurface geothermal energy. GEUS and the Danish Energy Agency have conducted a regional study to update the assessment of this potential; this work is summarised here, discussing future possibilities, including the geological risks and uncertainties. Wind power is another important energy source that contributes to $\mathrm{CO}_{2}$ reduction. Most future wind power will probably come from large offshore wind farms. GEUS has been involved in the preparation of several projects, including evaluation of seabed features and subsurface characteristics of possible sites. One paper describes a case story from the Kattegat.

GEUS works on many other aspects of the geology of Denmark, in particular in relation to groundwater and the environment. One paper describes the distribution and grain size of sand in the Miocene Billund delta. Understanding these depositional systems is scientifically important and applicable for modelling of groundwater and petroleum resources. A second paper presents a detailed geological model of an area in eastern Jylland, demonstrating how SkyTEM, stratigraphic and lithological data have been integrated to provide better input to groundwater models. A third paper is on pre-Holocene sediments from the Baltic Sea, discussing amino acid analysis of foraminifera and their application to age determination of the deposits. A fourth paper presents new results on the radon content in till deposits that seems to be controlled by age and redox conditions. This is important when evaluating health risks in houses in Denmark. Finally, the timing and possible causes of past nutrient enrichment in a lake in Jylland have been investigated. Such studies are essential to understanding the environmental threat to the ecosystem of the lake.

2009 was a historic year for the Continental Shelf Project of the Kingdom of Denmark. The first partial claim (the area north of the Faroe Islands) was submitted to the Commission of the Limit of the Continental Shelf (CLCS) in the spring. Furthermore, a large number of data-acquisition surveys were completed, including LOMROG II with the Swedish icebreaker Oden that visited the North Pole area. 
Data acquisition is now complete south of the Faroe Islands and south of Greenland. The technical work for the next submissions is well underway, but additional data from north-east and north of Greenland are still required. A status paper is given on the project, which started in 2003 and has progressed as planned. The project will continue until 2014, possibly requiring follow-up work and data management for several years until CLCS has submitted its recommendations to the United Nations.

In 2009, there was a high level of field activities on- and offshore Greenland. In addition to large campaigns in southern West, South-East, and East Greenland there were many other smaller activities. Results of ongoing work in southern West Greenland are described in two papers, one on the zircon record of the igneous and metamorphic history of the Fiskenæsset anorthosite complex, the other on the hydrothermal alteration and host rocks of a gold occurrence.

2009 was the first year in a mineral resource assessment project that is carried out together with the Greenland $\mathrm{Bu}$ reau of Minerals and Petroleum in one of the least known regions of Greenland, namely the logistically challenging south-east coast. A paper describes the start of the reconnaissance work that focussed on collecting stream sediments for an assessment of the economic potential of the area.

Field work and shallow core drilling in North-East Greenland continued in 2009. Related ore geology studies are described in a paper on application of airborne hyperspectral data in mineral exploration. In another part of East Greenland, GEUS has been involved in 3-D photogeological studies of analogues to intrabasaltic reservoir sandstones elsewhere in the North Atlantic region; these studies are presented in a paper that gives a good 3-D understanding and also provides details on reservoir properties.

Over many years, studies of the ice sheet and glaciers in Greenland have attracted strong international interest due to the implications of global sea-level rise. GEUS is involved in many glaciological and meteorological projects and monitoring programmes. Three papers focus on ice and climate.
The first describes the Greenland ice sheet monitoring network (GLISN) that records glacial earthquakes and provides important information on changes in glacier dynamics. The second presents results on bathymetry, shallow profiling and sediment coring in Sermilik near Helheimgletscher in SouthEast Greenland; work essential for studies of past ice fluctuations and their causes. The third is on glaciers in North-West Greenland with a case story on the advancing Berlingske Bræ glacier in a generally recessive ice regime.

GEUS works in many countries and with many projects types and has been active in Vietnam for several decades, in later years especially in the so-called ENRECA project that has completed two out of its three planned phases. A paper describes Vietnamese sedimentary basins, their geological evolution and petroleum potential. Another deals with offshore, thin-skinned thrust-fault tectonics.

Small-scale mining provides income for millions of people in Africa and Asia, but often with negative effects on the environment and health of miners, especially from the widespread use of mercury in gold extraction. GEUS has been involved in projects with the overall goal of reducing, or even stopping, the release of mercury into the environment. A case story from Tanzania with an alternative borax method is presented. The Survey has also been involved in many EU- and industry-financed projects of carbon-dioxide capture and storage in the past decade. The $\mathrm{COACH}$ project aims at applying this knowledge in China with its rapidly growing energy demand and where the use of coal-powered power stations is likely to continue for many years. A paper gives a first overview of $\mathrm{CO}_{2}$ sources, proposed pipe lines and potential storage sites in eastern China.

The final paper describes the results of a project carried out in cooperation with DuPont Titanium Technologies featuring interactive web applications of scanning electron microscopy data. This project has been successful, and similar methods are likely to be used in mineral and petroleum exploration and for other projects with large databases. 